\title{
Minimally invasive extracorporeal circulation in end-stage coronary artery disease patients undergoing myocardial revascularization
}

\author{
Ignazio Condello ${ }^{1^{*}} \mathbb{D}$, Giuseppe Santarpino 1,2,3, Francesco Bartolomucci ${ }^{4}$, Giovanni Valenti ${ }^{4}$, \\ Nicola Di Bari ${ }^{5}$, Marco Moscarelli ${ }^{1}$, Vincenza Vitobello ${ }^{1}$, Vera Triggiani ${ }^{1}$, Mario Gaudino ${ }^{6}$, Flavio Rimmaudo ${ }^{1}$, \\ Giuseppe Speziale ${ }^{1}$ and Giuseppe Nasso ${ }^{1}$
}

\begin{abstract}
Background: Patients with coronary artery disease and concomitant heart failure (left ventricular ejection fraction $<35 \%$ ) requiring myocardial revascularization are at risk of poor long-term prognosis and higher mortality. The benefits of minimally invasive extracorporeal circulation (MiECC), particularly in end-stage coronary artery disease patients undergoing myocardial revascularization, have not been completely described.

Materials and methods: In this single-centre control study, 60 end-stage coronary artery disease patients undergoing isolated coronary artery bypass grafting (CABG) were included. Patients were divided into two groups of 30 patients each undergoing CABG using MiECC or conventional extracorporeal circulation (CECC).

Results: In the MiECC group, oxygen delivery index $\left(\mathrm{DO}_{2 i}\right)$ was $305 \mathrm{~mL} / \mathrm{min} / \mathrm{m}^{2}$ in relation to indexed oxygen extraction ratio $\left(\mathrm{O}_{2} E R_{i}\right) 21.5 \%$, whereas in the $C E C C$ group $D_{2 i}$ was $288 \mathrm{~mL} / \mathrm{min} / \mathrm{m}^{2}$ in relation to $\mathrm{O}_{2} \mathrm{ER}_{\mathrm{i}} 25.6 \%(p=0.037)$. Lactate levels $>3 \mathrm{mmol} / \mathrm{L}$ were reported in 7 MiECC patients vs 20 CECC patients $(p=0.038)$, with blood glucose peak. Mean nadir hemoglobin values during cardiopulmonary bypass (CPB) were $9.7 \mathrm{~g} / \mathrm{dL}$ in the MiECC group vs $7.8 \mathrm{~g} / \mathrm{dL}$ in the $C E C C$ group $(p=0.044)$. Cardiac index during CPB was $2.4 \mathrm{~L} / \mathrm{min} / \mathrm{m}^{2}$ in both groups. Red blood cell units administered were 8 vs 21 units in the MiECC vs CECC group $(p=0.022)$. A glycemic peak was recorded in 7 patients of the MiECC group and in 20 patients of the CECC group $(p=0.037)$.

Conclusion: In end-stage coronary artery disease, the MiECC technique was associated with a higher $\mathrm{DO}_{2 \mathrm{i}}$ compared to $C E C C$. MiECC patients showed a significant reduction in red blood cell unit administration and peak intraoperative lactate levels, which correlated with better postoperative outcome.
\end{abstract}

Keywords: Minimally invasive extracorporeal circulation, MiECC, End-stage coronary artery disease, Coronary artery bypass grafting

*Correspondence: ignicondello@hotmail.it

${ }^{1}$ Department of Cardiac Surgery, Perfusion Service, GVM Care and Research, Anthea Hospital, Via Camillo Rosalba 35/37, 70124 Bari, Italy

Full list of author information is available at the end of the article

\section{Introduction}

Patients with coronary artery disease and concomitant heart failure (left ventricular ejection fraction $[\mathrm{LVEF}]<35 \%)$ requiring myocardial revascularization are at risk of poor long-term prognosis and higher mortality [1]. In this population, the appropriate selection of perioperative techniques and strategies is crucial for the original author(s) and the source, provide a link to the Creative Commons licence, and indicate if changes were made. The images or other third party material in this article are included in the article's Creative Commons licence, unless indicated otherwise in a credit line to the material. If material is not included in the article's Creative Commons licence and your intended use is not permitted by statutory regulation or exceeds the permitted use, you will need to obtain permission directly from the copyright holder. To view a copy of this licence, visit http://creativecommons.org/licenses/by/4.0/. The Creative Commons Public Domain Dedication waiver (http://creativecommons.org/publicdomain/zero/1.0/) applies to the data made available in this article, unless otherwise stated in a credit line to the data. 
prevention of acute kidney injury (AKI) that frequently occurs after cardiopulmonary bypass (CPB).

The management and monitoring of metabolic parameters during extracorporeal circulation (ECC) has gained widespread adoption over the years, particularly in relation to the target values of oxygen delivery $\left(\mathrm{DO}_{2}\right)>262 \mathrm{~mL} / \mathrm{min} / \mathrm{m}^{2}$, carbon dioxide production $>5.3$, indexed oxygen extraction ratio $\left(\mathrm{O}_{2} \mathrm{ER}_{\mathrm{i}}\right)<25 \%$ [2-4], with average blood pressure values during $\mathrm{CPB}$ of $50-70 \mathrm{mmHg}$. This has made it possible to reduce the incidence of postoperative AKI and to improve the management of aerobic vs anaerobic metabolism during cardiac surgery procedures. At the same time, minimally invasive ECC (MiECC) technologies have been developed and introduced into clinical practice [5].

The aim of this study was to compare MiECC vs conventional ECC (cECC) in patients with endstage coronary artery disease undergoing myocardial revascularization.

\section{Material and methods}

Population and study design

Between February 2020 and May 2021, 60 patients aged $>75-83$ years with a mean EuroSCORE II of 9.19.5\% and $\mathrm{LVEF}<35 \%$ underwent myocardial revascularization at our institution. A retrospective comparison was carried out in terms of maximum $\mathrm{DO}_{2}$ and $\mathrm{O}_{2} \mathrm{ER}_{\mathrm{i}}<25 \%$ for standard cardiac index $(\mathrm{CI})$ of $2.4\left(1 / \mathrm{min} / \mathrm{m}^{2}\right)$. Patients were divided into two groups: 30 patients underwent coronary artery bypass grafting (CABG) using MiECC and 30 patients underwent CABG using cECC (Table 1). Metabolic management through blood gas analysis integrated with the use of a metabolic parameter monitoring system during $\mathrm{CPB}$ was adopted in both groups.
The study protocol was approved by the local ethics committee (session June 2021) and all patients provided written informed consent to data treatment.

\section{Data collection}

Patients were selected according to the following criteria:

- Patients with coronary artery disease and concomitant heart failure $(\mathrm{LVEF}<35 \%)$ requiring myocardial revascularization, in whom complete $\mathrm{CPB}$ and cardioplegic arrest had to be foreseen with an expected CPB duration $>90$ min.

- Patients were excluded if they presented abnormal plasma lactate levels $(>2 \mathrm{mmol} / \mathrm{L})$ before entering $\mathrm{CPB}$, liver failure, obesity, uncompensated diabetes, autoimmune disease, active infection, any immunosuppressive therapy, or coagulation disorder. Patients undergoing combined surgery (e.g. aortic valve replacement $+C A B G$, about 300 patients during the study period) or surgery with circulatory arrest or having preoperative hematocrit $(\mathrm{Hct})<27 \%$ were also excluded.

All CABG procedures $(n=100)$ were analyzed for this study. Preoperative data included patient demographics, baseline serum creatinine, LVEF, comorbidities (chronic obstructive pulmonary disease, previous cerebrovascular accident), baseline hemoglobin (Hb), EuroSCORE II and New York Heart Association functional class [2].

Perioperative data included type of operation, CPB duration, nadir body temperature during $\mathrm{CPB}$, nadir Hct and $\mathrm{Hb}$ values (measured at the start of $\mathrm{CPB}$ and every 20 min thereafter), nadir $\mathrm{DO}_{2}$ index $\left(\mathrm{DO}_{2 \mathrm{i}}\right)$, nadir $\mathrm{DO}_{2 \mathrm{i}} /$ $\mathrm{O}_{2} \mathrm{ER}_{\mathrm{i}}$ ratio during $\mathrm{CPB}$, nadir $\mathrm{CI}$, nadir $\mathrm{CI} /$ mixed venous oxygen saturation $\left(\mathrm{SvO}_{2}\right)$, peak serum lactate and glucose

Table 1 Preoperative characteristics

\begin{tabular}{llll}
\hline & MiECC $(\mathbf{n}=\mathbf{3 0})$ & cECC $(\mathbf{n}=\mathbf{3 0})$ & $\mathbf{p}$ value \\
\hline Age (years), mean & 78.7 & 79.3 & 0.93 \\
Male sex, $n(\%)$ & $22(73)$ & $21(70)$ & 0.91 \\
Body surface area $\left(\mathrm{m}^{2}\right)$, mean & 1.79 & 1.78 & 0.99 \\
Left ventricular ejection fraction (\%), mean & 28 & 29 & 0.89 \\
EuroSCORE II (\%) & 9.1 & $32.6 \pm 1.9$ & 0.92 \\
Pre-CPB Hct (\%), mean \pm SD & $32.4 \pm 1.2$ & $11.8 \pm 1.2$ & 0.92 \\
Pre-CPB Hb (g/dL), mean \pm SD & $11.7 \pm 1.1$ & 5 & 0.94 \\
Chronic obstructive pulmonary disease, $n$ & 6 & $1.13 \pm 0.5$ & 0.96 \\
Creatinine (mg/dL), mean \pm SD & $1.14 \pm 0.2$ & 30 & 0.98 \\
Obstructive coronary artery disease & 30 & 3 & 1 \\
Peripheral arterial disease & 2 & & 0.98 \\
\hline
\end{tabular}

CECC, conventional extracorporeal circulation; MiECC, minimally invasive extracorporeal circulation; $\mathrm{CPB}$, cardiopulmonary bypass; $\mathrm{Hb}$, hemoglobin; $\mathrm{HCt}$, hematocrit; $\mathrm{SD}$, standard deviation 
during $\mathrm{CPB}$ and perioperative administration of red blood cell units.

Postoperative data included peak serum creatinine, mechanical ventilation time and days spent in the intensive care unit (ICU).

The primary endpoints were: maximum $\mathrm{DO}_{2 \mathrm{i}}$ in relation to $\mathrm{O}_{2} \mathrm{ER}_{\mathrm{i}}$ during $\mathrm{CPB}$ compared between groups in terms of intraoperative lactate and glycemia trends. Secondary endpoints were total red blood cell units transfused, peak postoperative serum creatinine [6-8], mechanical ventilation time, and length of ICU stay.

\section{Anesthetics and surgical procedures}

Patients were monitored with five-lead electrocardiography, a left radial artery catheter, capnography, pulse oximetry, and rectal/urine bladder temperature sensors. Transesophageal echocardiography was performed in all patients. Anticoagulant therapy consisted of heparin sodium before $\mathrm{CPB}$ at $300 \mathrm{IU} / \mathrm{kg}$ to achieve an activated clotting time of $>480 \mathrm{~s}$ (ACT PLUS Medtronic, Minneapolis, MN, USA); for heparin neutralization, 0.5-0.75 mg protamine was given for every 100 heparin units. Anesthesia was induced with intravenous sufentanil $(0.5-1 \mu \mathrm{g} / \mathrm{kg})$ and midazolam $(0.08-0.2 \mathrm{mg} / \mathrm{kg})$, and tracheal intubation was facilitated with intravenous rocuronium $(0.6-1 \mathrm{mg} / \mathrm{kg})$. Anesthesia was maintained with propofol $(2-5 \mathrm{mg} / \mathrm{kg})$ and sufentanil $(0.5-2.0 \mu \mathrm{g} /$ $\mathrm{kg}$ ), and bispectral index values (BIS XP, Aspect Medical System, Newton, MA, USA) were used for depth of anesthesia monitoring. The dosage of propofol was titrated to maintain bispectral index values between 40 and 60. Aortic valve replacement and CABG procedures were performed in median sternotomy with central cannulation, and surgical procedures were performed as routine by two surgeons. Concentrated red blood cells were transfused whenever $\mathrm{Hb}$ concentrations fell below $6 \mathrm{~g} / \mathrm{dL}$ during surgery or below $8 \mathrm{~g} / \mathrm{dL}$ during ICU stay. The goal of hemoconcentration was to eliminate the excess of crystalloid administration.

\section{Cardiopulmonary bypass setting MiECC group}

A closed MiECC type III circuit was employed using Stöckert S5 heart-lung machine (LivaNova, London, UK) [5], whose design presents the characteristics of a volume management circuit (MiECTiS classification). A shunted venous soft-shell reservoir (Closed, Eurosets, Medolla, Italy) was used, aortic root and pulmonary artery venous suction drainage was managed in sequence. The components (Biopassive Coating Phisio, LivaNova, London, UK) (Fig. 1) were as follows: venous-arterial line diameter (3/8), venous bubble-trap (Sherlock, Eurosets), a centrifugal pump (Biomedicus BPX80, Medtronic, Eden Prairie,
MN, USA), and a polypropylene fiber oxygenator (Alone, Eurosets). A bubble detection system was used to remove the air from the bubble trap and the circuit (Stockert, LivaNova). Circuit filling volume $500 \mathrm{~mL}$ crystalloid solution. $300 \mathrm{IU} / \mathrm{kg}$ of sodium heparin were administered, the activated clotting time prior to $\mathrm{CPB}$ was $501 \mathrm{~s}$, the cannulas were connected to the air-free circuit, and the bypass with a closed system was set up, the reference value of management of venous drainage was central venous pressure, maintained around $5 \mathrm{mmHg}$ using urapidil as a vasodilator for higher values, or upon request of drainage by the surgeon, the Trendelenburg position was used for lower values $[4,5,9,10]$. All patients were treated with mild hypothermic $\mathrm{CPB}\left(34-36{ }^{\circ} \mathrm{C}\right)$. For the administration of myocardial protection, a closed circuit for cardioplegia with heat exchanger, with an infusion syringe pump and Saint Thomas solution with procaine were used and repeated every $30 \mathrm{~min}$. The Landing monitoring system (Eurosets, Medolla, Italy) was used for $\mathrm{DO}_{2}$ management during $\mathrm{CPB}$. In both groups, blood gas analyses were performed using alpha-stat management with a blood gas analyzer (GEM Premier 3000 IQM, Instrumentation Laboratory, Werfen Group IVD company, Munchen, Germany) set to measure at $37{ }^{\circ} \mathrm{C}$ [11]. On the basis of arterial blood data, we assessed the lowest Hct (percentage) on CPB; every $20 \mathrm{~min}$, an arterial blood gas analysis, including blood glucose $(\mathrm{mg} / \mathrm{dL})$ and lactate $(\mathrm{mmol} / \mathrm{L})$ determination, was obtained. An $\mathrm{Hb}$ value $<6 \mathrm{~g} / \mathrm{dL}$ during $\mathrm{CPB}$ was considered the trigger point for red blood cell transfusion. All patients received tranexamic acid according to routine protocol. Mean arterial pressure during $\mathrm{CPB}$ procedures was managed for values between 55 and $70 \mathrm{mmHg}$.

\section{cECC group}

Open circuits with roller pumps (Admiral, Remo-well Eurosets, Medolla, Italy; Inspire $6 \mathrm{~F}$, LivaNova, London, UK) were used for CPB. Pericardial blood was collected separately and could be processed or reinjected, if needed. The hard shell and softshell reservoir, oxygenating module and circuits were treated with phosphorylcholine (Agile Eurosets, Medolla, Italy; Phisio, LivaNova, London, UK). All patients were treated with mild hypothermic CPB $\left(34-36^{\circ} \mathrm{C}\right)$; a volume of $1250 \mathrm{~mL}$ crystalloid Ringer acetate solution was used for priming. The surgical procedures selected for this study do not justify the use of moderate hypothermia by falling below $34^{\circ} \mathrm{C}$. For this reason, in the event of an initial increase in anaerobic metabolism, the first compensation approach was not to lower the temperature but possibly liquids or red blood cells were integrated.

The hardware consisted of a Stöckert S5 heart-lung machine and a Stöckert Heater Cooler System $3 \mathrm{~T}$ 


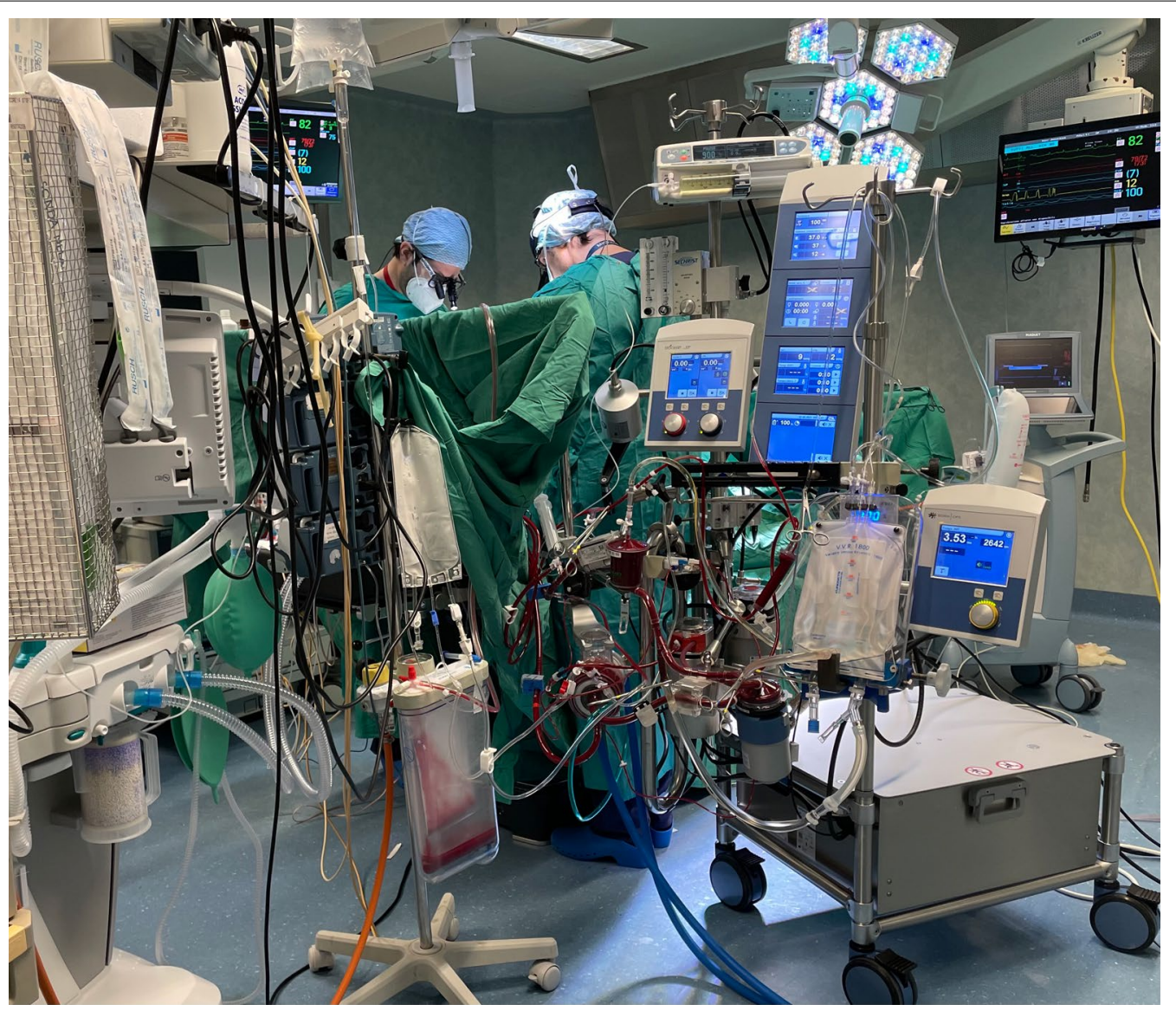

Fig. 1 Minimally invasive extracorporeal circulation (MiECC) during myocardial revascularization in end-stage coronary artery disease patients

(LivaNova, London, UK) and the same cannulae were employed in both groups. For the administration of myocardial protection, a closed circuit for cardioplegia with heat exchanger, with an infusion syringe pump in sequence and Saint Thomas solution with procaine were used and repeated every $30 \mathrm{~min}$. The Landing monitoring system (Eurosets, Medolla, Italy) was used for $\mathrm{DO}_{2}$ management during CPB. In both groups, blood gas analyses were performed using alpha-stat management with a blood gas analyzer (GEM Premier 3000 IQM, Instrumentation Laboratory, Werfen Group IVD company, Munchen, Germany) set to measure at $37{ }^{\circ} \mathrm{C}$ [11]. On the basis of arterial blood data, we assessed the lowest Hct (percentage) on CPB; every $20 \mathrm{~min}$, an arterial blood gas analysis, including blood glucose $(\mathrm{mg} / \mathrm{dL})$ and lactate $(\mathrm{mmol} / \mathrm{L})$ determination, was obtained. An $\mathrm{Hb}$ value $<6 \mathrm{~g} / \mathrm{dL}$ during $\mathrm{CPB}$ was considered the trigger point for red blood cell transfusion. All patients received tranexamic acid according to routine protocol. As in the MiECC group, mean arterial pressure during $\mathrm{CPB}$ procedures was managed for values between 55 and $70 \mathrm{mmHg}$.

\section{Statistics}

Statistical analysis was made according to Hickey's criteria. Continuous variables are presented as mean and standard deviation. As descriptive statistics, our results are not reported as inferential statistics. We used a routine statistical method, i.e. Student's t-test, which does not require extensive details.

\section{Results}

Demographic, preoperative and operative details of the patient population are shown in Tables 1 and 2. There were no difference between groups in preoperative characteristics; all patients had LVEF $<35 \%$ and underwent isolated CABG with prior risk assessment (EuroSCORE II 9.1-9.5\%).

In the MiECC group, oxygen delivery index $\left(\mathrm{DO}_{2 \mathrm{i}}\right)$ was $305 \mathrm{~mL} / \mathrm{min} / \mathrm{m}^{2}$ in relation to indexed oxygen extraction ratio $\left(\mathrm{O}_{2} E R_{\mathrm{i}}\right) 21.5 \%$, whereas in the cECC group $\mathrm{DO}_{2 \mathrm{i}}$ was $288 \mathrm{~mL} / \mathrm{min} / \mathrm{m}^{2}$ in relation to $\mathrm{O}_{2} \mathrm{ER}_{\mathrm{i}} 25.6 \%$ $(p=0.037)$. Lactate levels $>3 \mathrm{mmol} / \mathrm{L}$ were reported in 7 MiECC patients vs 20 cECC patients $(p=0.038)$, with blood glucose peak (Table 3). Mean nadir $\mathrm{Hb}$ values 
Table 2 Operative data

\begin{tabular}{|c|c|c|c|}
\hline & $\operatorname{MiECC}(n=30)$ & $\operatorname{cECC}(n=30)$ & $p$ value \\
\hline $\mathrm{CPB}$ time (min), mean $\pm \mathrm{SD}$ & $115 \pm 9.2$ & $110 \pm 6.17$ & 0.93 \\
\hline Aortic cross-clamp time (min), mean $\pm S D$ & $71 \pm 4$ & $69 \pm 6$ & 0.83 \\
\hline Nadir temperature during $\mathrm{CPB}\left({ }^{\circ} \mathrm{C}\right)$, mean $\pm \mathrm{SD}$ & $34.9 \pm 1.1$ & $34.7 \pm 2.1$ & 0.75 \\
\hline Nadir $\mathrm{Hb}$ value during $\mathrm{CPB}(\mathrm{mg} / \mathrm{dL})$, mean $\pm \mathrm{SD}$ & $9.7 \pm 1.5$ & $7.8 \pm 1.2$ & 0.044 \\
\hline Nadir Hct during CPB (\%), mean \pm SD & $29.8 \pm 0.3$ & $25.1 \pm 2.1$ & 0.043 \\
\hline Nadir $\mathrm{Hb}$ after $\mathrm{CPB}(\mathrm{mg} / \mathrm{dL})$, mean $\pm \mathrm{SD}$ & $9.4 \pm 0.1$ & $7.2 \pm 0.8$ & 0.044 \\
\hline Nadir Hct after CPB (\%), mean \pm SD & $29.2 \pm 0.1$ & $24.3 \pm 0.9$ & 0.045 \\
\hline Nadir $\mathrm{DO}_{2 \mathrm{i}}$ during $\mathrm{CPB}\left(\mathrm{mL} / \mathrm{min} / \mathrm{m}^{2}\right)$, mean $\pm \mathrm{SD}$ & $305 \pm 9$ & $288 \pm 6$ & 0.037 \\
\hline $\mathrm{O}_{2} \mathrm{ER}_{\mathrm{i}}$ during $\mathrm{CPB}(\%)$, mean $\pm \mathrm{SD}$ & $20 \pm 1$ & $25 \pm 3$ & 0.0029 \\
\hline Nadir $\mathrm{Cl}$ during $\mathrm{CPB}\left(\mathrm{L} / \mathrm{min} / \mathrm{m}^{2}\right)$, mean $\pm \mathrm{SD}$ & $2.4 \pm 0.2$ & $2.4 \pm 0.1$ & 0.94 \\
\hline Nadir $\mathrm{SvO}_{2}(\%)$ & $81 \pm 2$ & $75 \pm 5$ & 0.038 \\
\hline Crystalloid solution (mL) & $328 \pm 41$ & $727 \pm 57$ & 0.039 \\
\hline Red blood cells (units) & 8 & 21 & 0.021 \\
\hline Red blood cells during CPB (units) & 3 & 10 & 0.023 \\
\hline Red blood cells during ICU stay (units) & 5 & 11 & 0.024 \\
\hline
\end{tabular}

CECC, conventional extracorporeal circulation; MiECC, minimally invasive extracorporeal circulation; $\mathrm{Cl}$, cardiac index; $\mathrm{CPB}$, cardiopulmonary bypass; $\mathrm{DO}{ }_{2}$, indexed oxygen delivery; $\mathrm{Hb}$, hemoglobin; $\mathrm{Hct}$, hematocrit; ICU, intensive care unit; $\mathrm{O}_{2} \mathrm{ER}_{\mathrm{i}}$, indexed oxygen extraction ratio; $\mathrm{SD}$, standard deviation; $\mathrm{SvO} \mathrm{O}_{2}$, mixed venous oxygen saturation

Table 3 Peak blood lactate and $\mathrm{DO}_{2 \mathrm{i}}$ in relation to $\mathrm{O}_{2} \mathrm{ER}_{\mathrm{i}}$ during cardiopulmonary bypass in the MiECC and CECC groups

\begin{tabular}{lll}
\hline & $\begin{array}{l}\text { No } \\
\text { hyperlactatemia or } \\
\text { hyperglycemia }\end{array}$ & $\begin{array}{l}\text { Hyperlactatemia } \\
\text { and } \\
\text { hyperglycemia }\end{array}$ \\
\hline MiECC & & \\
No. patients & 23 & 7 \\
Peak blood lactate $(\mathrm{mmol} / \mathrm{L})$ & $1.08 \pm 0.19$ & $1.93 \pm 0.25$ \\
${\text { Mean } \mathrm{DO}_{2 \mathrm{i}}\left(\mathrm{mL} / \mathrm{min} / \mathrm{m}^{2}\right)}$ & $304 \pm 21$ & $275 \pm 19$ \\
Mean $\mathrm{O}_{2} \mathrm{ER}_{\mathrm{i}}(\%)$ & $20 \pm 3$ & $38 \pm 4$ \\
Blood glucose $(\mathrm{mg} / \mathrm{dL})$ & $129 \pm 9$ & $205 \pm 11$ \\
cECC & & \\
No. patients & 10 & 20 \\
Peak blood lactate $(\mathrm{mmol} / \mathrm{L})$ & $1.28 \pm 0.45$ & $3.91 \pm 1.21$ \\
Highest $\mathrm{DO}_{2 \mathrm{i}}\left(\mathrm{mL} / \mathrm{min} / \mathrm{m}^{2}\right)$ & $289 \pm 11$ & $265 \pm 19$ \\
Highest $\mathrm{O}_{2} \mathrm{ER}_{\mathrm{i}}(\%)$ & $25 \pm 3$ & $33 \pm 4$ \\
Blood glucose $(\mathrm{mg} / \mathrm{dL})$ & $149 \pm 3$ & $230 \pm 11$ \\
\hline
\end{tabular}

Values are given as mean \pm standard deviation. CECC, conventional extracorporeal circulation; $\mathrm{DO}_{2 i}$, indexed oxygen delivery; MiECC minimally invasive extracorporeal circulation; $\mathrm{O}_{2} \mathrm{ER}_{\mathrm{i}}$ indexed oxygen extraction ratio

during CPB were $9.7 \mathrm{~g} / \mathrm{dL}$ in the MiECC group vs $7.8 \mathrm{~g} /$ $\mathrm{dL}$ in the cECC group $(p=0.044)$. CI during CPB was $2.4 \mathrm{~L} / \mathrm{min} / \mathrm{m}^{2}$ in both groups. As for liquid administration, including anesthesia infusions, $727 \mathrm{~mL}$ and $328 \mathrm{~mL}$ of crystalloid solution were given to MiECC and cECC patients, respectively ( $p=0.039)$ (Table 2). Red blood cell units administered were 8 vs 21 units in the MiECC vs cECC group $(p=0.022)$. A glycemic peak was recorded in
Table 4 Hyperlactatemia during cardiopulmonary bypass and postoperative outcome

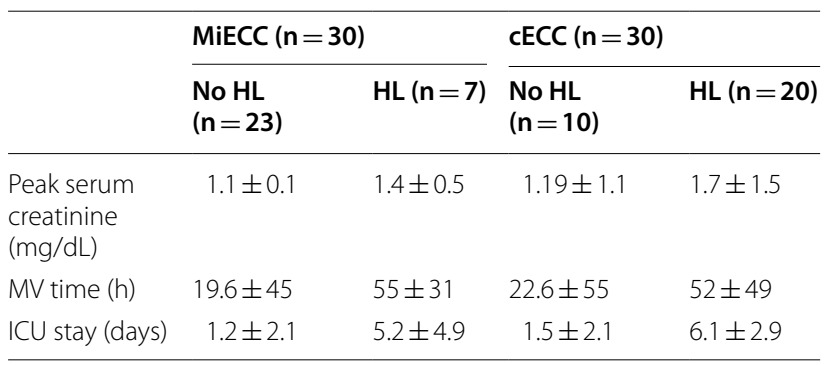

Values are given as mean \pm standard deviation. $\mathrm{CECC}$, conventional extracorporeal circulation; MiECC minimally invasive extracorporeal circulation; $\mathrm{HL}$, hyperlactatemia; ICU, intensive care unit; MV, mechanical ventilation

7 patients of the MiECC group and in 20 patients of the cECC group $(p=0.037)$. Patients with hyperlactatemia during $\mathrm{CPB}$ showed a significant increase in serum creatinine [7], higher rate of prolonged mechanical ventilation and longer ICU stay (Table 4). No patient underwent ultrafiltration during $\mathrm{CPB}$.

\section{Discussion}

This retrospective study aimed at comparing two different CPB techniques (i.e. MiECC type III vs cECC) in end-stage coronary artery disease patients undergoing myocardial revascularization in terms of $\mathrm{DO}_{2 \mathrm{i}}$ values in relation to $\mathrm{O}_{2} \mathrm{ER}_{\mathrm{i}}$ with the same target $\mathrm{CI}$, and of incidence of peak lactate and correlation with postoperative outcome. More specifically, the type of ECC technique 
can influence intraoperative $\mathrm{DO}_{2 \mathrm{i}}$ with blood product use but hemodilution being equal. In other words, mean $\mathrm{DO}_{2} \mathrm{i}$ was higher in the MiECC group compared to the cECC group with higher $\mathrm{Hb}$ and Hct, though with less transfusions administered since the flow rate of the two circuits would have been the same. The reduced hemodilution with MiECC can also account for the better results obtained in this group in terms of lower $\mathrm{O}_{2} \mathrm{ER}_{\mathrm{i}}$. The relationship between hyperlactatemia and hyperglycemia through the above mechanism was confirmed by Revelly et al. in 2005 [12] in an elegant study on cardiogenic or septic shock. The role of adrenergic agonists in this setting is well defined: in cardiogenic shock, these drugs are either endogenous or administered for cardiovascular therapy; in our model, they were endogenous in the majority of patients. None received epinephrine during $\mathrm{CPB}$, and few received norepinephrine; however, unlike epinephrine, norepinephrine usually does not increase glucose production or induce an increase in plasma lactate concentration [13-15]. The two mechanisms leading to hyperlactatemia in various clinical conditions are therefore (1) anaerobic metabolism due to a poor $\mathrm{DO}_{2}$, and (2) excess lactate production due to glucose failing to enter the oxidative pathway and being degraded to lactate by the glycolytic pathway $[13,15,16]$. These mechanisms, if independently considered, lead to different acid-base balance conditions, the former being accompanied by metabolic acidosis and the latter not necessarily so. However, in the clinical conditions of this observational study, the acid-base balance is constantly maintained at a normal $\mathrm{pH}$ value by bicarbonate corrections applied by the perfusionist whenever the base excess starts decreasing. Therefore, we were unable to identify differences in hyperlactatemia related to different values of peak blood lactate. However, the evidence that only four patients showed hyperlactatemia without hyperglycemia and that only patients with a hyperlactatemia-hyperglycemia syndrome had significantly lower $\mathrm{DO}_{2}$ values seems to confirm that, in our specific clinical environment, hyperlactatemia and hyperglycemia are linked by the causative factor of a poor $\mathrm{DO}_{2}$. This leads on one hand to lactate production through the anaerobic pathway and on the other hand to a vicious cycle of lactate production due to the poor ability to use glucose through the aerobic pathway $[3,6,11,17]$. Reduced oxygen content in cases of acute anemia is usually compensated by reduced blood viscosity with increased blood flow in the microcirculation and by a compensatory increase in cardiac output [18]. This last mechanism may be impaired during $\mathrm{CPB}$, where pump flow is usually adjusted on the basis of the patient's body surface area and temperature, not the $\mathrm{Hb}$ value. On the basis of our data, the main rationale for explaining hyperlactatemia during $\mathrm{CPB}$ is a $\mathrm{DO}_{2}$ inadequate to guarantee the needed oxygen consumption of the patient.

In the present study, we investigated the role of potentially modifiable factors related to $\mathrm{CPB}$ during $\mathrm{CABG}$ surgery in determining postoperative hyperlactatemia (e.g. due to inadequate perfusion) and hyperglycemia [19]. Our results demonstrate that a $\mathrm{DO}_{2 \mathrm{i}}<270 \mathrm{~mL} / \mathrm{min} /$ $\mathrm{m}^{2}$ with $\mathrm{O}_{2} \mathrm{ER}_{\mathrm{i}}>35 \%$ and low $\mathrm{CI}\left(<2.4 \mathrm{~L} / \mathrm{min} / \mathrm{m}^{2}\right)$ with $\mathrm{SvO}_{2}<65 \%$ during $\mathrm{CPB}$ are associated with hyperlactatemia and hyperglycemia and $\mathrm{DO}_{2 \mathrm{i}}>290 \mathrm{~mL} / \mathrm{min} / \mathrm{m}^{2}$ with $\mathrm{O}_{2} \mathrm{ER}_{\mathrm{i}}<25 \%$ and $\mathrm{CI}>2.4 \mathrm{~L} / \mathrm{min} / \mathrm{m}^{2}$ with $\mathrm{SvO}_{2}>75 \%$ during $\mathrm{CPB}$ are associated with a low incidence of hyperlactatemia and hyperglycemia. Various preoperative factors or comorbidities may create the right environment for hyperlactatemia during CPB. Age, female gender, congestive heart failure, low LVEF, hypertension, atherosclerosis, diabetes, preoperative $\mathrm{Hb}$ value, redo or complex surgery, and emergency procedures were found to be risk factors for hyperlactatemia by Demers and coworkers [20], who reported an hyperlactatemia incidence of $18 \%$. Some of these factors were confirmed in our study, and other new factors were identified. However, our study population had a significantly shorter CPB duration and a lower degree of hemodilution during CPB. Given that both these factors seem to favor the onset of hyperlactatemia, the lower hyperlactatemia rate in our population is reasonably explained. The role of $\mathrm{CPB}$ duration in the development of hyperlactatemia during $\mathrm{CPB}$ has been highlighted in other studies [2, 20,21]. Moreover, the additional volume of crystalloid in the $\mathrm{CECC}$ group resulted in significant hemodilution as indicated by the mean $\mathrm{Hb}$ values which were more than $2 \mathrm{~g} / \mathrm{dL}$ greater for the MiECC group during CABG. This factor alone could have had a large impact on the other dependent variables, including lactate levels and oxygen delivery.

\section{Study limitations}

Several limitations should be acknowledged. First, this is a single-centre study with a small sample size. Second, we did not know the microcirculation response for the higher $\mathrm{Hb}$ values in the MiECC group compared to the cECC group. Third, there were no inflammatory markers (cytokines) that could affect postoperative outcome, including $\mathrm{DO}_{2 \mathrm{i}}$. Fourth, eight pre- and intraoperative factors were found to be significantly associated with peak blood lactate levels during $\mathrm{CPB}$ at univariate analysis (i.e. age, isolated coronary operation, lowest pump flow/blood pressure, requirement of vasopressor or inotropic medications, lowest temperature, Hct, and $\mathrm{DO}_{2 \mathrm{i}}$ ) which were negatively correlated with peak blood lactate levels during $\mathrm{CPB}$, whereas $\mathrm{CPB}$ duration and peak blood glucose were positively correlated with peak blood lactate levels during $\mathrm{CPB}$. Notwithstanding this, the 
samples were homogeneous as for the characteristics. The Landing monitoring system was used for $\mathrm{DO}_{2}$ management during $\mathrm{CPB}$; however, we did not record time durations $<280 \mathrm{~mL} / \mathrm{min} / \mathrm{m}^{2}$. Finally, the availability of perfusionists with and without skills for managing the MiECC technique is another limitation of the study.

\section{Conclusion}

End-stage coronary artery disease patients undergoing myocardial revascularization with the MiECC technique had a higher $\mathrm{DO}_{2 \mathrm{i}}$ in relation to $\mathrm{O}_{2} \mathrm{ER}_{\mathrm{i}} 20-25 \%$ compared to patients operated on with the cECC technique. MiECC patients showed a significant reduction in blood red cell units administered, in the incidence of peak intraoperative lactate, which correlated with reduced postoperative serum creatinine and shorter mechanical ventilation and ICU stay, as compared to CECC patients.

\section{Acknowledgements}

None.

\section{Authors' contributions}

I.C. participated in manuscript writing, revision and conception. G.S. writing the manuscript. F.B. and G.V. gives support in conception. N.D. and M.M. participated in conception and manuscript vision. V.V. and V.T. gives support in statistical analysis. M.G. and F.R. participated in support and supervision. G.S. participated in support and conception. G.N. participated in support, rewriting and revision. All authors read and approved the final manuscript.

\section{Funding}

None.

\section{Availability of data and materials}

The datasets used and analysed during the current study are available from the corresponding author on reasonable request.

\section{Declarations}

\section{Ethics approval and consent to participate}

The study was evaluated and approved by the institutional board for clinical trials, Anthea Hospital GVM Care\&Research (internal protocol; decision 2020 Feb) and Informed consent was obtained from all subjects involved in the study.

\section{Consent for publication}

All authors have read and agreed to the published version of the manuscript.

\section{Competing interests}

The authors declare that they have no competing interests.

\section{Author details}

${ }^{1}$ Department of Cardiac Surgery, Perfusion Service, GVM Care and Research, Anthea Hospital, Via Camillo Rosalba 35/37, 70124 Bari, Italy. ${ }^{2}$ Department of Cardiac Surgery, Paracelsus Medical University, Nuremberg, Germany. ${ }^{3}$ Cardiac Surgery Unit, Department of Experimental and Clinical Medicine, University "Magna Graecia" of Catanzaro, Catanzaro, Italy. ${ }^{4}$ ASL BAT, Andria, Italy. ${ }^{5}$ Division of Cardiac Surgery, Dipartimento di Emergenza e Trapianti di Organo (D.E.T.O.), University of Bari, Bari, Italy. ${ }^{6}$ Department of Cardiothoracic Surgery, Weill Cornell Medicine, New York, NY, USA.

Received: 19 May 2021 Accepted: 24 November 2021

Published online: 27 December 2021

\section{References}

1. Szlapka M, Hetzer R, Ennker J, Hausmann H. Conventional cardiac surgery in patients with end-stage coronary artery disease: yesterday and today. Cardiovasc Diagn Ther. 2021;11:202-12.

2. Ranucci M, Isgrò G, Romitti F, Mele S, Biagioli B, Giomarelli P. Anaerobic metabolism during cardiopulmonary bypass: the predictive value of carbon dioxide derived parameters. Ann Thorac Surg. 2006:81:2189-95.

3. Ranucci M, De Toffol B, Isgrò G, Romitti F, Conti D, Vicentini M. Hyperlactatemia during cardiopulmonary bypass: determinants and impact on postoperative outcome. Crit Care. 2006;10:167.

4. de Somer F, Mulholland JW, Bryan MR, Aloisio T, Van Nooten GJ, Ranucci $\mathrm{M} . \mathrm{O}_{2}$ delivery and $\mathrm{CO}_{2}$ production during cardiopulmonary bypass as determinants of acute kidney injury: time for a goal-directed perfusion management? Crit Care. 2011;15:R19.

5. Anastasiadis K, Antonitsis P, Haidich AB, Argiriadou H, Deliopoulos A, Papakonstantinou $C$, et al. Use of minimal extracorporeal circulation improves outcome after heart surgery; a systematic review and meta-analysis of randomized controlled trials. Int J Cardiol. 2013;164:158-69.

6. Maillet JM, Le Besnerais P, Cantoni M, Nataf P, Ruffenach A, Lessana A, et al. Frequency, risk factors, and outcome of hyperlactatemia after cardiac surgery. Chest. 2003;123:1361-6.

7. Mehta RL, Kellum JA, Shah SV, Molitoris BA, Ronco C, Warnock DG, et al. Acute Kidney Injury Network: a report of an initiative to improve outcomes in acute kidney injury. Crit Care. 2007;11:R31.

8. Mehta RH, Grab JD, O'Brien SM, Bridges CR, Gammie JS, Haan CK, et al. Bedside tool for predicting the risk of postoperative dialysis in patients undergoing cardiac surgery. Circulation. 2006;114:2208-16.

9. Benedetto U, Angeloni E, Refice S, Capuano F, Goracci M, Roscitano A, et al. Is minimized extracorporeal circulation effective to reduce the need for red blood cell transfusion in coronary artery bypass grafting? Meta-analysis of randomized controlled trials. J Thorac Cardiovasc Surg. 2009;138:1450-3.

10. Biancari F, Rimpilainen R. Meta-analysis of randomised trials comparing the effectiveness of miniaturised versus conventional cardiopulmonary bypass in adult cardiac. Heart. 2009;95:964-9.

11. Landow L. Splanchnic lactate production in cardiac surgery patients. Crit Care Med. 1993;21:S84-91.

12. Revelly JP, Tappy L, Martinez A, Bollmann M, Cayeux MC, Berger MM, et al. Lactate and glucose metabolism in severe sepsis and cardiogenic shock. Crit Care Med. 2005;33:2235-40.

13. Totaro R, Raper RF. Epinephrine induced lactic acidosis following cardiopulmonary bypass. Crit Care Med. 1997;25:1693-9.

14 Rashkin MC, Bosken C, Baughman RP. Oxygen delivery in critically ill patients. Relationship to blood lactate and survival. Chest. 1985;87:580-4.

15. Ensinger H, Geisser W, Brinkmann A, Wachter U, Vogt J, Radermacher P, et al. Metabolic effects of norepinephrine and dobutamine in healthy volunteers. Shock. 2002;18:495-500.

16 Ranucci M, Isgrò G, Romitti F, Mele S, Biagioli B, Giomarelli P. Anaerobic metabolism during cardiopulmonary bypass: predictive value of carbon dioxide derived parameters. Ann Thorac Surg. 2006;81:2189-95.

17. Boldt J, Piper S, Murray P, Lehmann A. Severe lactic acidosis after cardiac surgery: sign of perfusion deficits. J Cardiothorac Vasc Anesth. 1999;13:220-4.

18. Habib RH, Zacharias A, Schwann TA, Riordan CJ, Durham SJ, Shah A. Adverse effects of low hematocrit during cardiopulmonary bypass in the adult: should current practice be changed? J Thorac Cardiovasc Surg. 2003;125:1438-50.

19. Raper RF, Cameron G, Walker D, Bovey CJ. Type B lactic acidosis following cardiopulmonary bypass. Crit Care Med. 1997;25:46-51.

20. Demers P, Elkouri S, Martineau R, Couturier A, Cartier R. Outcome with high blood lactate levels during cardiopulmonary bypass in adult cardiac surgery. Ann Thorac Surg. 2000;70:2082-6.

21. Weil MH, Afifi AA. Experimental and clinical studies on lactate and pyruvate as indicators of the severity of acute circulatory failure (shock). Circulation. 1970;41:989-1001.

\section{Publisher's Note}

Springer Nature remains neutral with regard to jurisdictional claims in published maps and institutional affiliations. 